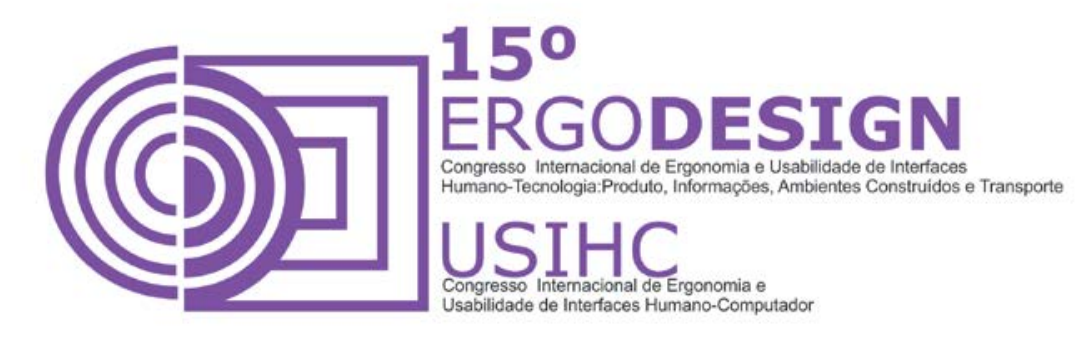

\title{
ANÁLISE MACROERGONÔMICA DO TRABALHO NO SETOR ADMINISTRATIVO DE UMA EMPRESA DE CONFECÇÃO
}

\section{WORK MACROERGONOMIC ANALYSIS IN A ADMINISTRATIVE DEPARTMENT OF A APPAREL INDUSTRY}

\author{
ASSIS, Mônica (1) \\ BATISTA, Raquel Meireles (2) \\ ZERBETTO, Cristiane Affonso de Almeida (3)
}

(1) Universidade Estadual de Londrina (UEL), graduada em Design de Moda

email: rachel-mb@hotmail.com

(2) Unicesumar, graduada em Moda

email: monicassis@gmail.com

(3) Universidade Estadual Paulista Júlio de Mesquita Filho (UNESP), professora doutora

email: cra@uel.br

\section{RESUMO}

Este trabalho teve como intuito executar a Análise Macroergonômica do Trabalho(AMT) no setor administrativo de uma empresa de confecção.O método de pesquisautilizado para a obtenção dos resultados, é um método participativo, onde os funcionários envolvidos na pesquisa podem opinar e auxiliar na resolução dos problemas da empresa.

Palavras chave: macroergonomia, confecção, setor administrativo.

\section{ABSTRACT}

This work aims to analyze the labor Macroergonomics in the management department of an apparel industry. The chosen methodology to obtaining the aimed results has a collaboration strategy, where staff are involved throughout the research by providing feedback and assisting in the business problems solving.

Key words: macroergonomic, apparel industry, management department 


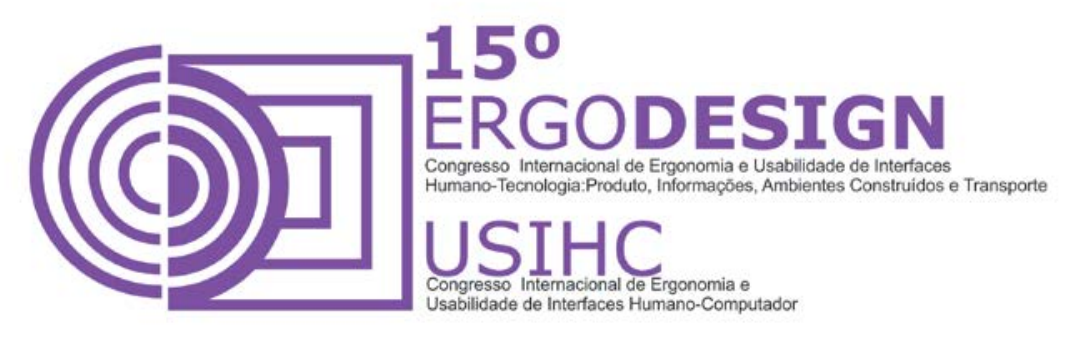

\section{INTRODUÇÃO}

O olhar científico sobre o trabalho na indústria surge, efetivamente, com o engenheiro norteamericano Frederick Taylor, a partir de estudos publicados no começo do século XX, que defendiam que o trabalho deveria ser observado cientificamente, determinando tempo, ferramentas $\mathrm{e}$ movimentos ideais para a execução das tarefas fabris.

Durante décadas o taylorismo, termo que define a ideia de cronometragem do trabalho, foi sofrendo diversas mudanças, e muitos dos métodos antes adotados foram descartados, pois percebeu-se que o ambiente social e o relacionamento com os colegas poderiam ser tão motivadores quanto o salário e o ambiente físico (IIDA, 2005). Isso exigiu uma nova abordagem do trabalho na indústria, eliminando gradativamente as linhas de produção, deixando de controlar individualmente o trabalhador, expondo objetivos e metas claramente ao grupo de trabalho.

Como expõe lida (2005), diferente dos trabalhos na indústria, que vem recebendo melhorias e contribuições por décadas, as pesquisas sobre trabalhos de escritório são mais recentes. Levando em conta o crescimento de empresas no setor de serviços prestados à empresas, como escritórios de contabilidade, arquitetura, contabilidade e advocacia, consequentemente cresce a demanda por mão de obra e a necessidade de se pensar e projetar com cuidado para estes trabalhadores.

Tendo como base estes apontamentos, o objetivo desta pesquisa foi analisar e propor melhorias para os trabalhadores do setor administrativo de uma empresa de confecção, localizada em Maringá, Paraná. Visto que toda linha de produção e demais setores da empresa já sofreram análise de especialistas em ergonomia, ficando os trabalhadores do escritório sem este amparo.

\section{ERGONOMIA E MACROERGONOMIA, BREVE INTRODUÇÃO}

Segundo lida (2005), ergonomia é a ciência que estuda a adaptação do trabalho ao homem, sendo trabalho não só o sistema que envolve uma máquina, mas toda relação entre o homem e uma atividade produtiva. Essa ciência busca planejar e projetar essa relação, podendo ocorrer antes de sua realização, durante ou depois. A ergonomia busca meios para adaptar o trabalho ao indivíduo considerando suas capacidades e limitações. As pessoas que estudam e aplicam os conceitos de ergonomia, são chamados de ergonomistas, segundo lida (2005, p.3), "os ergonomistas devem analisar o trabalho de forma global, incluindo os aspectos físicos, cognitivos, sociais, organizacionais, ambientes e outros". A ergonomia pode ser dividia em diferentes especialidades, segundo o autor, dentre elas; ergonomia física, cognitiva e organizacional. lida (2005) defende que a ergonomia procura trazer eficiência ao sistema produtivo, estudando os fatores que agem sobre 0 desempenho deste, procurando reduzir a fadiga, estresse, erros e acidentes, garantindo então segurança e saúde aos trabalhadores.

A macroergonomia é uma vertente da ergonomia relacionada também ao aspecto organizacional do ambiente, além do físico e do cognitivo. Segundo Bugliani (2007), os princípios da macroergonomia vem do final da década de 80 , decorrente de uma necessidade de considerar uma abordagem mais ampla do trabalho, abordando também os aspectos organizacionais, pensando e projetando o todo, por isso o termo macro. Kleiner (1998 apud BUGLIANI, 2007) explica que a abordagem macroergonômica caracteriza-se como participativa, pois considera a contribuição dos trabalhadores na reorganização do ambiente de trabalho ligada a análise dos especialistas envolvidos. 


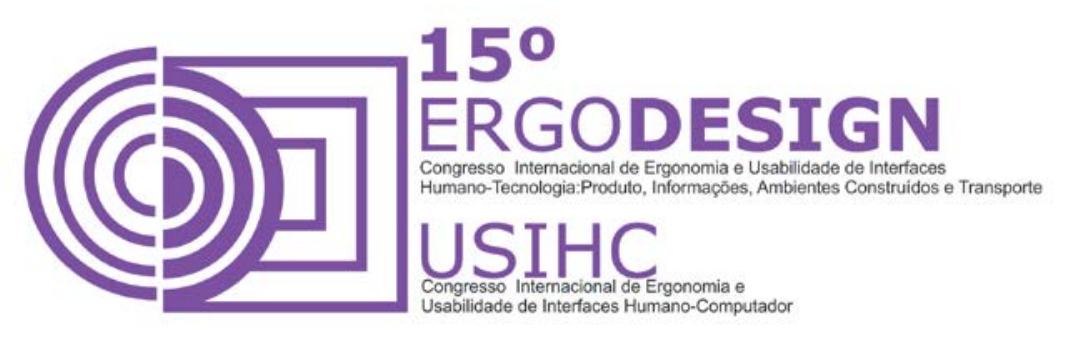

\section{CARACTERIZAÇÃO DA EMPRESA}

A empresa abordada nesta pesquisa está no mercado há mais de 21 anos desenvolvendo produtos no segmento de lingerie, sendo este divido em duas linhas: lingerie dia e lingerie modeladora. É uma organização paranaense de administração familiar que se iniciou do projeto de um casal, onde a esposa costurava na própria casa e o marido vendia nas cidades da região. Com o aumento da demanda, houve a necessidade de contratação de costureiras e, posteriormente, de representantes. Quando foram contratados mais colaboradores, a empresa foi formalizada e mudou-se para outro local.

Em pouco tempo a empresa já tinha dois galpões e mais de 50 funcionários. A partir disso, a organização precisou criar departamentos e contratar uma equipe administrativa. Paralelo a isso, a empresa iniciou um trabalho com a CIPA (Comissão Interna de Prevenção de Acidentes), que organizou a produção da empresa ergonomicamente, mas esse processo não verificava profundamente as necessidades da equipe administrativa.

Atualmente, a empresa atende quase todos os estados brasileiros, além de exportar para o Paraguai e Suíça e atuar com e-commerce. Esta conta com aproximadamente 60 funcionários internos e 30 representantes externos, sendo a maior parte composta por mulheres. A empresa está dividida basicamente em três áreas: criação, produção e administração.

\section{1 caracterização do setor investigado}

O recorte para esta pesquisa se deu no setor administrativo, principalmente pela formação recente do setor e pelo fato deste ainda não estar envolvido totalmente em nenhum projeto ergonômico.

A equipe administrativa, foco deste estudo, é composta por: uma assistente financeiro, uma gerente comercial, um responsável por TI (Tecnologia da Informação), uma auxiliar financeiro e uma estagiária de marketing. Sendo as demais atividades realizadas pelos diretores e vice- diretores dessa empresa, aqui não pesquisados. O setor administrativo cumpre carga horária de trabalho de 44 horas semanais, com eventuais horas extras, sendo essas alternadas em pagamentos e banco de horas. A maior parte da equipe almoça no refeitório da empresa, a qual não oferece o almoço, apenas o espaço.

A presente pesquisa analisa o grau de satisfação dos funcionários em tudo o que está envolvido diretamente e indiretamente na realização do trabalho.

\section{METODOLOGIA}

Para realizar a pesquisa foi utilizado o método Análise Macroergonômica do Trabalho (AMT), com base nas informações de Guimarães (2010). Este utiliza a ergonomia participativa como base para a identificação das necessidades organizacionais e a implantação de melhorias, através de um planejamento de prioridades. O objetivo é envolver os trabalhadores no encontro de problemas e soluções, considerando que são eles que estão diretamente envolvidos na estrutura da empresa. 


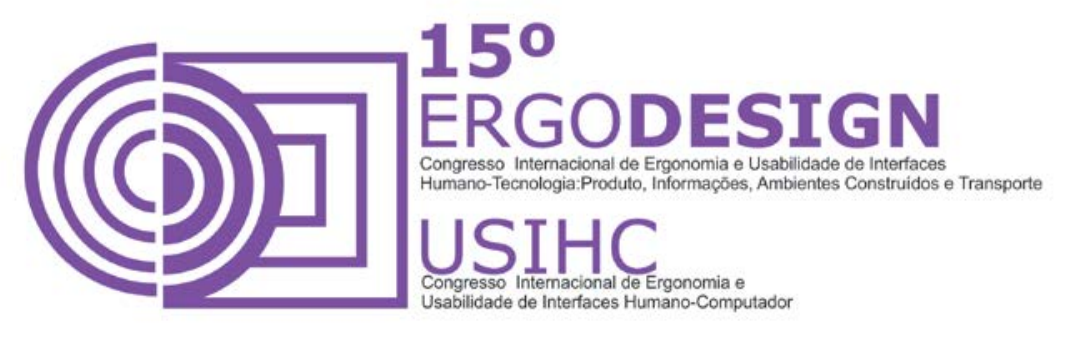

Assim, melhorar a satisfação dos profissionais, fidelizá-los à organização, garantir maior produtividade e, consequentemente, a lucratividade da empresa.

Segundo Guimarães (2010), o propósito deste método é detectar os problemas que estão relacionados à qualidade de vida e segurança no trabalho, considerando as variáveis ambientais, tecnológicas, físicas e interpessoais. Sendo o mesmo composto por cinco etapas: levantamento ou apreciação ergonômica; análise da situação ou diagnose ergonômica; propostas de soluções; validação de soluções e detalhamento ergonômico. Partindo desses pontos, Hendrick (2002) defende que os trabalhadores quando envolvidos no processo de mudança sentem-se compromissados com a empresa, engajados com metas e objetivos e abertos a implantação de melhorias.

Para aplicação do método, foi selecionado o setor administrativo da empresa com a participação de cinco pessoas. Salientando que este estudo acompanhou apenas até a fase de projeção de soluções. Na primeira etapa, foi realizada a apreciação ergonômica do ambiente laboral, onde foram tiradas fotos para a avaliação e observação dos IDES (Itens de Demanda Ergonômica), preliminares sob a visão apenas dos pesquisadores. Em seguida, foi realizada a diagnose ergonômica, aplicando-se uma entrevista e um questionário formado pelos IDES aos colaboradores. Posteriormente, foi apresentado aos diretores da organização os IDES que estavam abaixo da média de satisfação $(7,5)$. Já na fase de indicação de soluções, os funcionários participaram novamente para traçar um planejamento com ordem de prioridades para implantação de melhorias.

\subsection{Apreciação Macroergonômica}

A primeira fase da pesquisa consistiu em uma exploração e análise do ambiente de trabalho dos funcionários do setor estudado, registrando, através de fotos, os pontos que as pesquisadoras consideravam como empecilhos no desempenho das atividades nos escritórios.

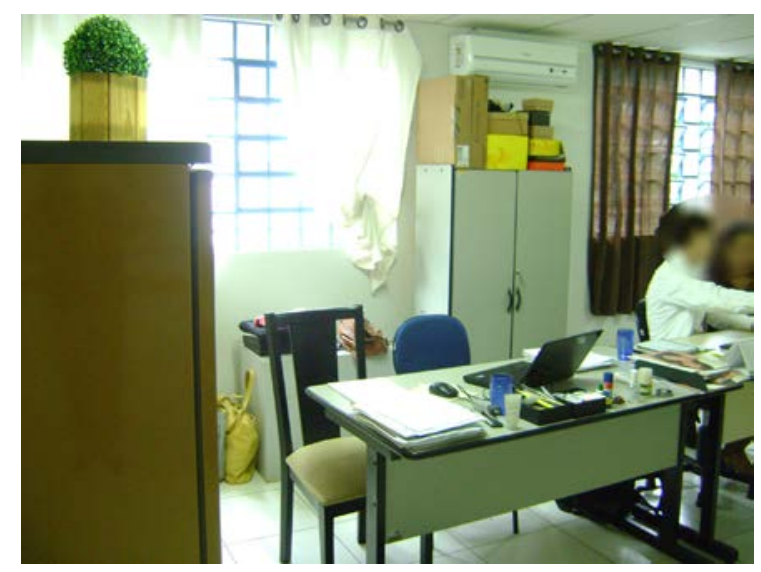

Figura 1 - Uma das salas do setor administrativo

Fonte: do autor 


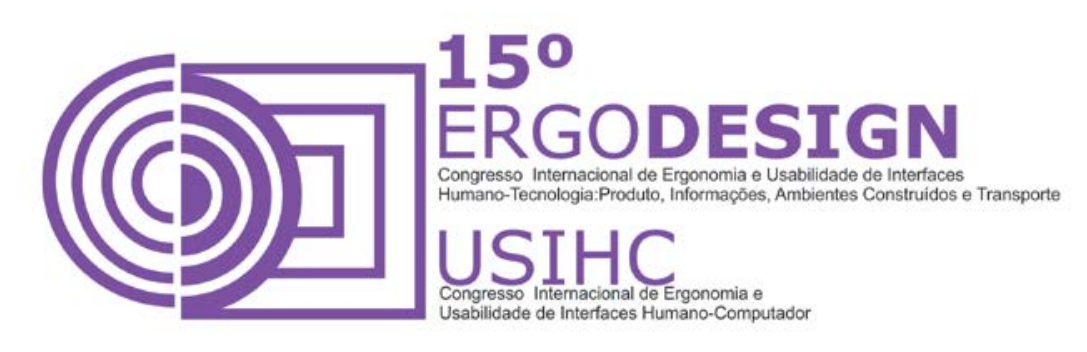

Nesta imagem pode-se observar a cadeira inadequada para trabalho, além de altura desconfortável para trabalho com computador.

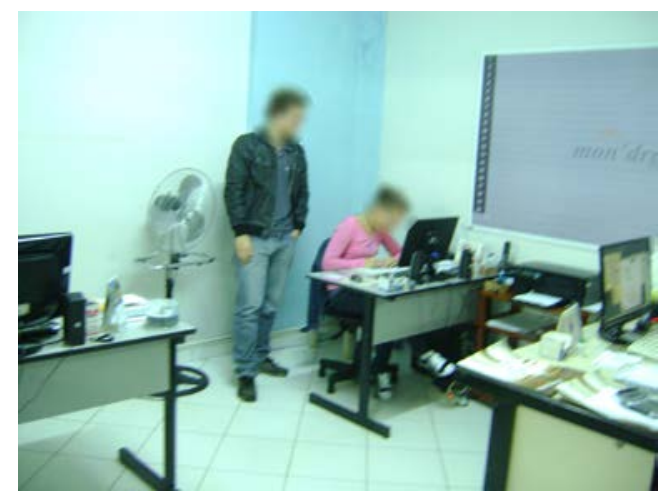

Figura 2 - Detalhe do uso do computador e do ventilador.

Fonte: do autor.

Nesta imagem pode-se perceber que o ventilador usado para controlar a temperatura da sala não consegue ventilar todo o ambiente, tornando-se um problema em dias muito quentes.

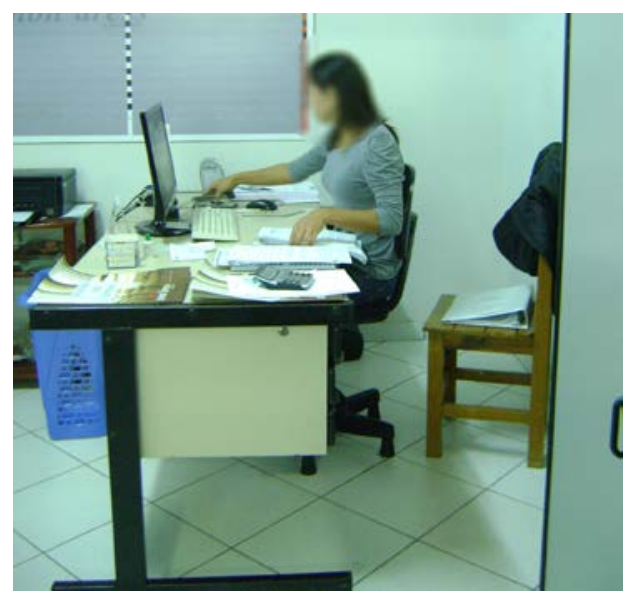

Figura 3 - Falta de mesa para apoio.

Fonte: do autor. 


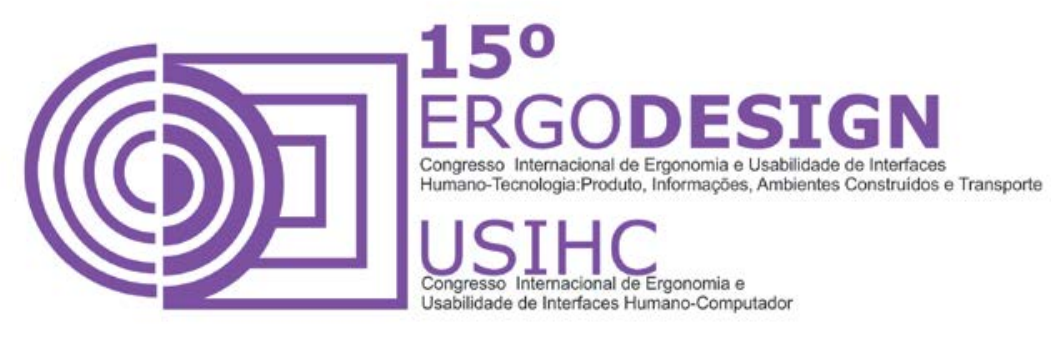

Nesta imagem pode-se perceber o pouco espaço para armazenamento das notas ficais e documentos com os quais a funcionária trabalha. Além de observar uma cadeira ao lado que ela usa para auxiliar na organização dos papéis.

\section{2 - DIAGNOSE MACROERGONÔMICA}

A segunda fase da pesquisa consistiu na reunião dos trabalhadores do setor administrativo da empresa, para uma conversa informal, a fim de explicar o intuito da pesquisa e a melhora que se pretendia proporcionar aos aspectos do ambiente de trabalho e à empresa consequentemente. Após a conversa, distribui-se o material para a entrevista, papel e caneta, para que os trabalhadores pudessem elencar até cinco pontos que mais incomodavam 0 desempenho de seu trabalho, sejam estes aspectos físicos, organizacionais ou cognitivos, chamados de Itens de Demanda Ergonômica (IDE's). Os funcionários elencaram os pontos individualmente para que um não inferisse nas respostas do outro.

Os resultados da entrevista foram tabulados e organizados de acordo com a ordem de prioridade elencada pelo entrevistado, utilizando a fórmula $1 / x$, sendo $x=$ a colocação do item de acordo com a resposta do trabalhador. O item mais importante foi colocado em primeiro lugar, ou seja, 1/1=1, o de segunda relevância em segundo lugar, 1/2=0,5 e assim por diante, não sendo obrigatório elencar cinco pontos necessariamente. Através desta fórmula, foram calculados os pesos das respostas dos funcionários e tabulados para análise, expostos na Tabela 1.

Tabela 1-Itens de demanda ergonômica elencados pelos funcionários do setor administrativo da empresa.

\begin{tabular}{|l|l|l|l|l|l|l|}
\hline & C1 & C2 & C3 & C4 & C5 & SOMA \\
\hline $\begin{array}{l}\text { sala muito quente durante o } \\
\text { verão }\end{array}$ & & & 0,3 & 1 & 1 & 2,33 \\
\hline $\begin{array}{l}\text { muitas pessoas conversando } \\
\text { no mesmo }\end{array}$ & 1 & & 1 & & & 2 \\
\hline $\begin{array}{l}\text { ambiente desconcentra o } \\
\text { trabalho }\end{array}$ & & & & & & \\
\hline $\begin{array}{l}\text { cadeira baixa e sem apoio } \\
\text { para os braços }\end{array}$ & 1 & & 0,3 & & 1,25 \\
\hline $\begin{array}{l}\text { falta de tampa nos vasos } \\
\text { sanitários }\end{array}$ & & 0,33 & & 0,2 & & 0,55 \\
\hline $\begin{array}{l}\text { ventilador atrapalha a } \\
\text { organização }\end{array}$ & & & & & 1 & 0,5 \\
\hline dos papéis na mesa & & & & & & \\
\hline
\end{tabular}




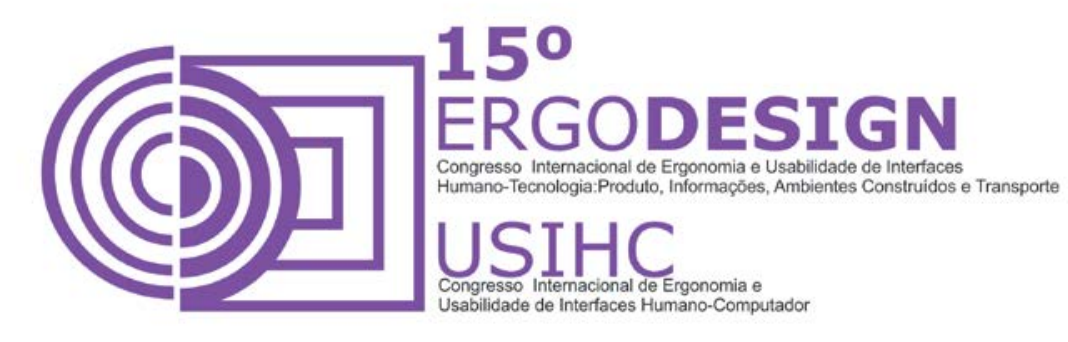

\begin{tabular}{|l|l|l|l|l|l|l|} 
falta de espelho nos banheiros & & & & 0,5 & & 0,5 \\
\hline $\begin{array}{l}\text { altura do monitor do } \\
\text { computador }\end{array}$ & 0,5 & & & & & 0,5 \\
\hline mesas desconfortavéis & & 0,5 & & & & 0,5 \\
\hline $\begin{array}{l}\text { internet cai sempre } \\
\text { falta de garrafa de chá e } \\
\text { bolachas na }\end{array}$ & & & 0,5 & & & 0,5 \\
\hline sala & & & & & & \\
\hline cheiro de cola na sala & & & & 0,3 & & 0,33 \\
\hline corrente de ar frio & 0,3 & & & & & 0,33 \\
\hline $\begin{array}{l}\text { pouco espaço para } \\
\text { armazenamento }\end{array}$ & & & & & 0 & 0,25 \\
\hline das notas fiscais & & & & & & 0,47 \\
\hline falta de microondas na cozinha & & & & 0,2 & & 0,16 \\
\hline iluminação da sala ruim & & & & 0,1 & & 0,12 \\
\hline
\end{tabular}

Fonte: do autor.

Após a análise dos dados coletados na entrevista com os funcionários, elaborou-se um questionário com 20 questões seguindo o método da AMT. Este questionário foi respondido pelos mesmos funcionários já envolvidos no processo, eles avaliaram o grau de satisfação ou importância dos itens classificados.

As questões eram respondidas através de uma escala de avaliação contínua de $15 \mathrm{~cm}$, com âncoras no seu ponto máximo e mínimo, assim como sugerido por Stone et al. (apud GUIMARÃES et al., 2010). Os colaboradores deviam marcar um ponto nessa linha referente à sua percepção sobre o item, podendo variar de 0 a 15 o nível de satisfação ou importância, sendo 0 (insatisfação) e 15 (satisfação) e 0 (pouco importância) e 15 (muita importância).

Após a aplicação individual do questionário, foram levantados os resultados através da mensuração das linhas e calculada uma média aritmética para cada IDE (Item de Demanda Ergonômica). Os resultados obtidos geraram dois gráficos, Figura 4 e Figura 5, o primeiro com o grau de satisfação e o segundo com o nível de importância dados pelos colaboradores. Para o gráfico de satisfação, os valores abaixo da média $(7,5)$ foram observados com mais atenção, já para o gráfico de nível de importância, a avaliação foi inversa, os valores acima da média $(7,5)$ eram os quais deveriam ser revistos. 

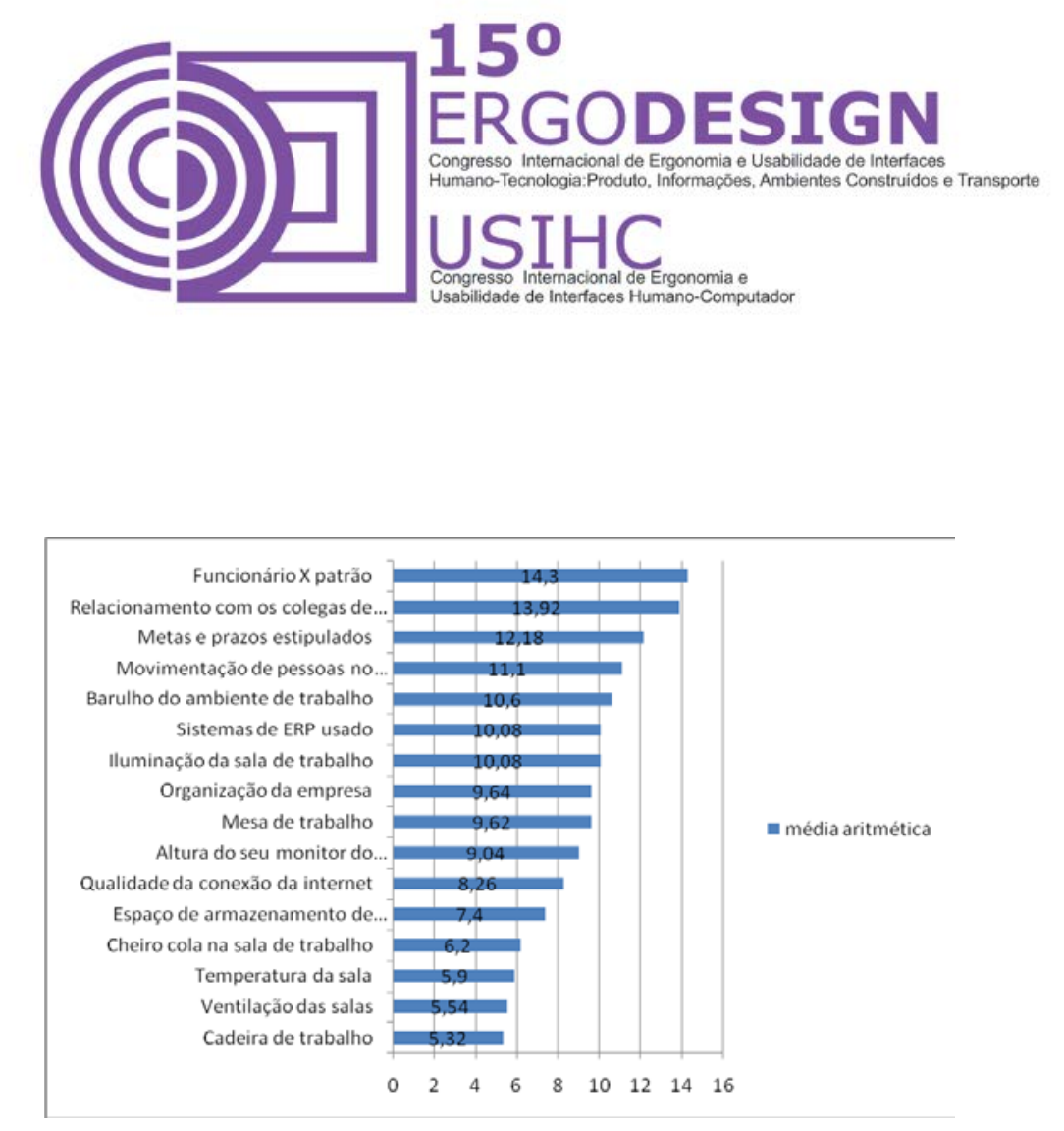

Figura 4 - Gráfico com o grau de satisfação dado pelos funcionários com relação aos IDE’s selecionados.

Fonte: do autor.

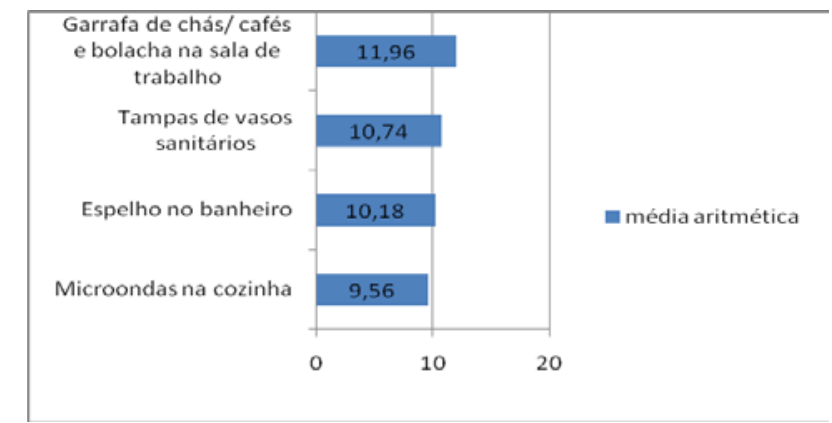

Figura 5 - Gráfico com o nível de importância dada pelos funcionários com relação aos IDE's selecionados.

Fonte: do autor.

\subsection{Projetação Macroergonômica}

A partir dos dados coletados, foi possível reunir os colaboradores do setor investigado e debater sugestões de melhorias e as prioridades de implantação para melhorar a qualidade macroergonômica do trabalho. Foi verificado que dos 20 itens questionados, 5 apresentaram-se 


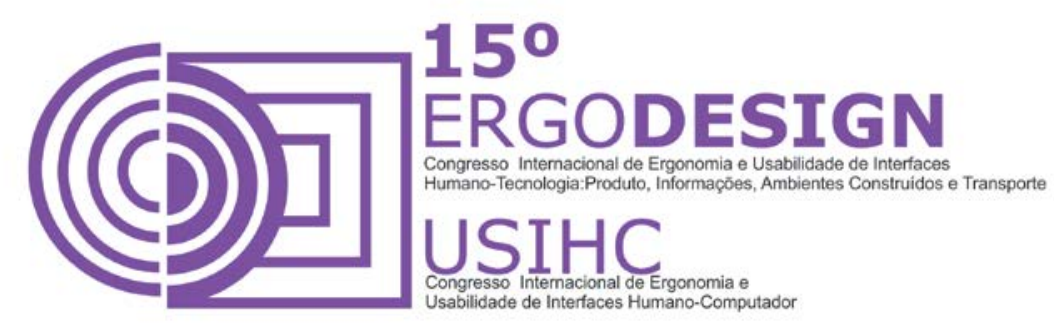

abaixo da média 7,5 no quesito baixo grau de satisfação e 4 estiveram acima da média 7,5 no quesito alto nível de importância. Assim, estes itens receberam o foco para a implantação de melhorias.

\subsubsection{Grau de satisfação}

\section{Cadeira de trabalho $(5,32)$}

Segundo Brandimiller (2002), a cadeira indicada para trabalhar em escritórios com computadores é a denominada giratória com encosto, assento e braços de regulagem. Estas possuem assento giratório com 40 a $45 \mathrm{~cm}$ de largura e 38 a $42 \mathrm{~cm}$ de profundidade, base com cinco pés com rodízios, encosto curto e oscilante para apoio lombar separado do assento com altura de $50 \mathrm{~cm}$. Além de fornecer a cadeira adequada, é necessário orientar os usuários quanto à postura correta na posição sentada e a altura dos braços da cadeira para o apoio no uso do mouse. As cadeiras também devem receber manutenções para verificar se as mesmas oferecem o conforto e a funcionalidade ideal indicada pela boa qualidade ergonômica.

Neste projeto foi verificado que alguns funcionários já possuíam a cadeira adequada, porém elas não tinham braço, assim foi programada a compra dos braços e de mais duas cadeiras que estavam faltando, além da manutenção da qualidade das cadeiras que estão em uso e orientação doa juste da cadeira de acordo com o usuário.

\section{Ventilação das salas $(5,54)$ e Temperatura das salas $(5,9)$}

Os dois itens tratam do mesmo problema, ou seja, o conforto térmico das salas de trabalho. Esta não possui janelas, dificultando a troca de calor com o ambiente externo. Os funcionários elencaram estes itens como de segunda e terceira maior insatisfação, após a discussão com os mesmos, verificou-se que as salas de trabalho eram muito quentes, e o sistema utilizado para ventilação (um grande ventilador), além de não ser suficiente para conter o calor, atrapalhava o andamento do serviço de uma das funcionárias da sala que emite notas fiscais. Segundo ela, o ventilador produz vento forte que faz os papéis saírem do lugar. Como expõe lida (2005, $p$. 498), "A norma ISO 9241 recomenda temperaturas de 20 a $24^{\circ} \mathrm{C}$ no inverno e 23 a $26^{\circ} \mathrm{C}$ no verão, com umidade relativa oscilando entre 40 e $80 \%$. Acima de $24^{\circ} \mathrm{C}$ os trabalhadores sentem sonolência e abaixo de $18^{\circ} \mathrm{C}$, aqueles envolvidos em trabalhos sedentários, começam a sentir tremores". Segundo Bredford e Vernon (1922apud IIDA 2005), a temperatura é algo muito importante para o desempenho do trabalhador, sendo a partir de $24^{\circ} \mathrm{C}$ que se aumentam as chances de acidentes. Além disso, os autores defendem que a eficiência do trabalhador cai conforme aumenta a temperatura do ambiente de trabalho, com $28^{\circ} \mathrm{C}$ a eficiência é $41 \%$ menor que a $19^{\circ} \mathrm{C}$.

Portanto, o sistema mais adequado para controlar a temperatura da sala é a instalação de um aparelho de ar condicionado, assim não atrapalharia o trabalho da emissão de notas fiscais e conteria o calor excessivo que os trabalhadores sentem. 


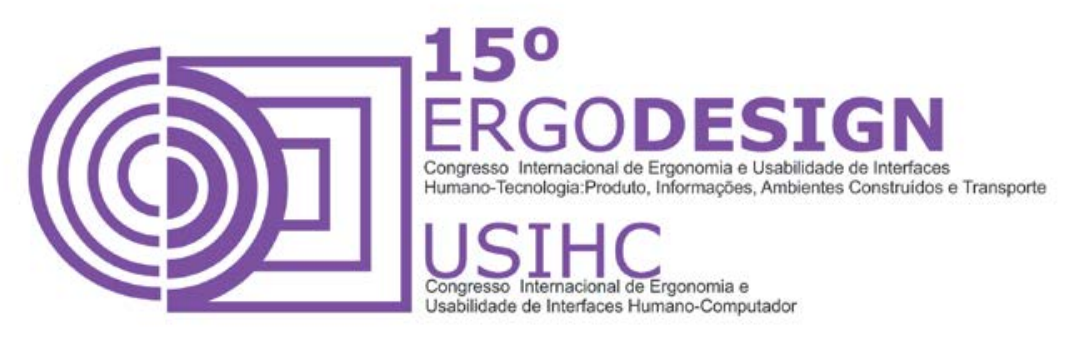

\section{Cheiro de Cola na Sala de Trabalho $(6,2)$}

$\mathrm{Na}$ empresa o setor administrativo fica ao lado do departamento de despacho de mercadorias, sendo que o cheiro da cola usada para fechar as caixas incomoda diretamente os colaboradores. O interessante é que o levantamento de dados apresentou que somente as mulheres se incomodam com o cheiro da cola, e como no setor de despacho de mercadoria só trabalham homens este problema nunca tinha sido apontado. Inclusive este mesmo setor já passou pela verificação da CIPA (Comissão Interna de Prevenção de Acidentes), onde foi analisado que o cheiro da cola não fazia mal a saúde.

Neste caso, foi sugerida a procura de uma nova cola para se trabalhar, algo que não tenha um cheiro ruim e que também não faça mal à saúde, tendo em vista que devido ao espaço e ao fluxo do trabalho não é possível trocar os departamentos de lugar.

\section{Espaço para Notas Fiscais $(7,4)$}

No departamento administrativo também estão alocadas as impressoras, por ser uma sala de comum acesso aos outros departamentos. Neste caso, outros colaboradores começaram a armazenar materiais de impressão de uso de outros setores junto aos materiais de trabalho do setor administrativo, num espaço que também já se armazenava os arquivos de papéis. Para lida (2005), somente materiais relacionados ao trabalho devem estar organizados junto ao ambiente de trabalho, estes devem estar classificados por tipos, tamanhos, de maneira organizada. Cada tipo de objeto deve ter um lugar certo para ser guardado e o mesmo vale para arquivos em papéis e eletrônicos.

Diante disso, foi sugerida a realocação de um armário para o departamento administrativo para guardar somente materiais de impressão de uso comum a todos que utilizam as impressoras, e assim deixar o armário já existente na sala para guardar materiais de uso de trabalho do setor administrativo.

\subsubsection{Nível de importância}

\section{Microondas na cozinha $(9,56)$}

Este foi o item de maior importância elencado pelos funcionários. Como a empresa não oferece refeição, cada funcionário deve trazer sua refeição (almoço), mas estas são aquecidas em cubas de água quente, o que demora certo tempo.

Os funcionários e a empresa chegaram a conclusão, durante discussão após a aplicação dos questionários, que o mais adequado será comprar dois aparelhos de microondas, pois estes serão mais práticos e rápidos para aquecer as refeições. 


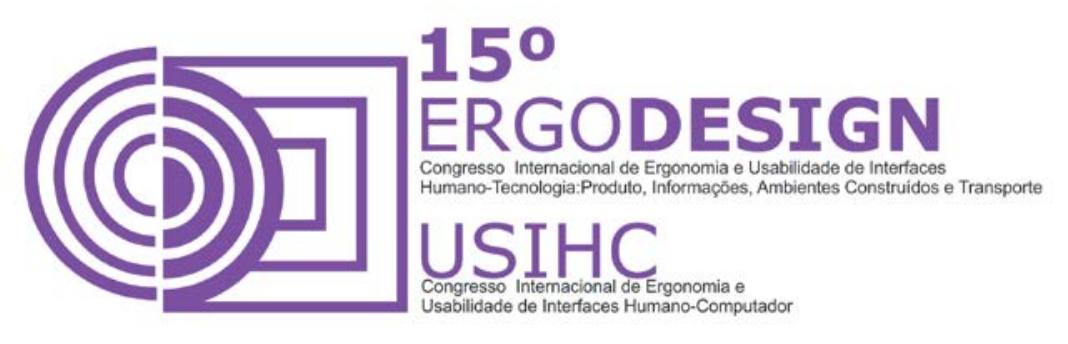

\section{Espelho no Banheiro (10,18)}

Foi verificado que os banheiros da empresa não possuem espelhos e os colaboradores sentem falta do mesmo para auxiliar na higiene bucal e também no cuidado com o visual, nas horas de intervalo. Porém, os mesmos banheiros usados para a hora de intervalo são usados durante 0 horário de trabalho, prevendo-se que a existência de espelho no banheiro poderia implicar em uma prolongação do tempo do uso do banheiro na hora do expediente. De tal modo, explicada a seguinte situação aos colaboradores, foi sugerido que eles tivessem acesso a loja da fábrica, a qual está localizada dentro da própria empresa, para utilização dos provadores, onde há espelhos, para o cuidado com o visual e verificação da higiene bucal.

\section{Tampas de Vasos Sanitários (10,74)}

Segundo especialistas usar o vaso sanitário sem a tampa ou mesmo com a tampa aberta é uma fonte de disseminação de sujeiras, expondo as pessoas que usam o banheiro a doenças. "Cientistas concluíram que a bactéria Clostridium difficile, conhecida por causar diarreia, é lançada cerca de 25 centímetros em torno do vaso sempre que é dada a descarga". O estudo foi publicado no Journal of Hospital Infextion. "Abaixar a tampa reduziria substancialmente esse tipo de contaminação." (ZH NOTÍCIAS, 2013).

Neste caso, foi sugerido que comprassem as tampas dos vasos sanitários, o mais rápido possível, para os quatro banheiros que não tinham tampas.

\section{Garrafa de chá/café na sala de trabalho $(11,96)$}

Os funcionários declararam sentir uma necessidade de ter uma garrafa com chá ou café na sala de trabalho para tomar durante as pequenas pausas que fazem durante o expediente. Segundo a NR 24 do Ministério do Trabalho, a empresa não é obrigada a fornecer café e chá aos funcionários, apenas água potável para beber. Mas a fim de melhorar o conforto dos funcionários para as pequenas pausas efetuadas, sugere-se que seja oferecido até duas garrafas de café ou chá por dia.

\section{CONCLUSÃO}

A partir dos resultados da pesquisa pôde-se perceber a importância e relevância da AMT como um método para implantar melhorias no ambiente de trabalho. Diferente de outros métodos este tem como intuito incluir não só a visão do trabalhador sobre seu posto de trabalho, mas também agregar suas sugestões na implantação dessas melhorias, tornando-se assim mais eficaz. Itens que as pesquisadoras achavam que seriam relevantes não foram considerados empecilhos para os funcionários, reforçando a importância de ouvir as pessoas que estão em contato diário com o ambiente e atividades desempenhadas.

Lembrando que estudos focados em postos de trabalho são bastante comuns, vale salientar, contudo, que a análise de setores específicos como um todo ainda é recente. Portanto, esta 


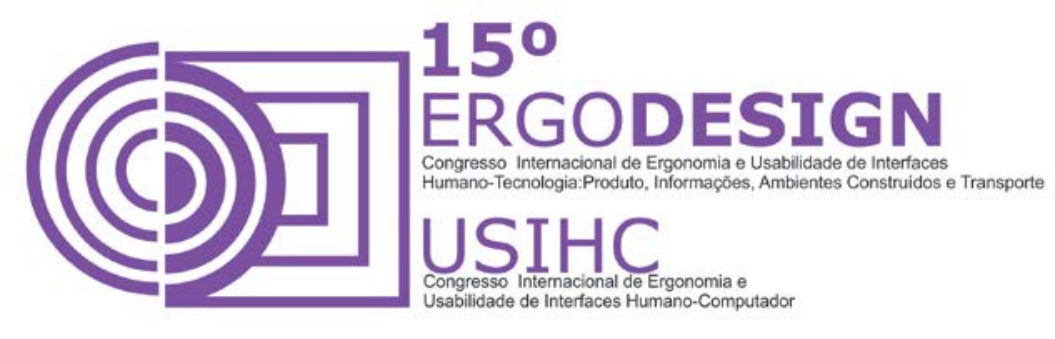

investigação deverá acrescentar às pesquisas existentes na área uma experiência com resultados julgados como altamente positivos, tanto para os funcionários, como para os proprietários da empresa. Neste sentido podemos dizer que a pesquisa obteve êxito no que se propôs na busca dos IDE's (Itens de Demanda Ergonômica) e soluções mais próximas da realidade da empresa estudada.

\section{REFERÊNCISA BIBLIOGRÁFICAS}

BRANDIMILLER, Primo A. O corpo no trabalho: guia de conforto e saúde para quem trabalha em microcomputadores. 2.ed. São Paulo: Senac, 2002.

BUGLIANI, Raquel de Oliveira. Macroergonomia: um panorama do cenário brasileiro. Bauru, 2007. Dissertação. (Mestrado em Design). UNESP. Disponível em:<https://www.faac.unesp.br/Home/PosGraduacao/Design/Dissertacoes/raquelbugliani.pdf>. Acesso em: 30 de maio de 2014.

GUIMARÃES, Lia Buarque Macedo. Macroergonomia: colocando conceitos em prática. Porto Alegre: Feeng, 2010.

HENDRICK, H. W.; KLEINER, B. M. Macroergonomics: theory, methods and applications. New Jersey: Taylor \& Francis e-Library, 2009.

IIDA, Itiro. Ergonomia: projeto e produção.2.ed. São Paulo: E. Blucher, 2005.

PASCHOARELLI, L. C.; SILVA, J. C. P. Design ergonômico: estudos e aplicações. São Paulo: Canal, 2013.

SIMONI, C. G; ZERBETTO, C. A. A. Análise macroergonômica em uma empresa da construção civil. Disponível em: <http://www.uel.br/revistas/uel/index.php/projetica/article/viewFile/7725/6856>. Acesso em: 30 maio, 2014.

ZH NOTÍCIAS. Tampar o vaso sanitário ao dar a descarga impede infestação de bactéria causadora da diarreia. Disponível em: <http://zh.clicrbs.com.br/rs/noticias/noticia/2013/06/tampar-o-vaso-sanitarioao-dar-a-descarga-impede-infestacao-de-bacteria-causadora-da-diarreia-4160429.html>. Acesso em: 21 jun, 2014. 